\section{Bad advice on AIDS}

\section{President Reagan should counter the defects of} his new AIDS panel by risking his own popularity.

How should a government go about seeking advice on a difficult problem that threatens its people's public health? One way, the bad way, is to find a group of people who subscribe to the government's ideology, paying little or no attention to the expertise they may possess. The recommendations of this panel can be counted on to be "correct"in that they will conform to the government's own views of the world, but they would not be likely to break new ground. Another way, for the sake of argument "the good way", is to assemble people with genuine and first-hand knowledge of the problem, whose preconceptions, in the nature of things, are likely to be divergent opinions about how it should be approached. Such a group is certain to present its sponsoring government with difficult choices, some of which would certainly fly in the face of its ideology. But such a group might at least also suggest creative and effective solutions, leaving political and ideological problems to others better equipped to handle them.

President Ronald Reagan, faced with the need to decide how the United States should respond to the problem of AIDS (acquired immune deficiency syndrome), has chosen the bad way (see page 372 ). His advisory panel consists of people whose ideological qualifications are clear, but whose expertise on AIDS is not just suspect but non-existent. Theresa Crenshaw, the sex therapist from San Diego, supports abstinence from sexual activity as a general prophylactic against AIDS. That is symptomatic of a philosophy already espoused by the Reagan Administration for "wrong" behaviour of which it disapproves: "Just say no." This approach has not worked for drug abusers, and will not control the spread of HIV infection.

AIDS presents special problems for a country such as the United States which is uncomfortable dealing with issues relating to sexual behaviour. It is ironic that a president as popular as Mr Reagan is probably the only person who could openly tell the United States, without alienating his listeners, that AIDS is a particularly insidious (and dangerous) often-venereal disease whose spread will be successfully controlled only if people give thought to the nature and the safety of their sexual practices. If, for example, he were to tell the United States that people at risk should be careful to use condoms, there is a chance that they would believe him. But Mr Reagan will not take that chance. Although only a small fraction of those suffering from AIDS in the United States are children - homosexuals are still the majority - the president, during his visit to the National Institutes of Health last week, chose to have his photograph taken last week with a black haemophiliac child suffering from AIDS. The gesture may have helped to convince some who saw it that HIV is not an airborne infection like the common cold, but it will have done nothing to carry home to US citizens the stark truth that AIDS is laying waste to an identifiable and substantial part of the population of the United States. Is it that he would prefer not to acknowledge, or to be seen by his supporters to acknowledge, that homosexuals exist?

The pity in all this is that there is little doubt what needs most urgently to be done. Last year's excellent report from the National Academy of Sciences and the Institute of Medicine made it crystal-clear that explicit public education is an essential first step. Getting at young adults would require mass advertising not very different from that which has startled (and sometimes shocked) people in places as different as Australia and Britain, in the process acknowledging that many modern practices now common - pre-marital intercourse and drug abuse as well as homosexuality - do not easily fit in with the mores of polite conventional society. Beyond public education, there are stronger nettles to be grasped, questions of the balance between personal liberty and communal health, that will be tackled wisely only by well-prepared communities. Yet these are the issues for which the US government needs advice. The panel now appointed will deliver nothing of the sort. President Reagan may know that in advance. Meanwhile, he could do worse than use his popularity to force open the tight moral lid that his conservative advisors would like to see placed on the problem of how to live with and, with good judgement, to survive AIDS. $\square$

\section{Jumbos in the skies}

\section{The planned merger between Britain's two largest airlines raises questions of principle.}

AIR transport has for decades deserved better from the governments that regulate its affairs, or otherwise interfere. So much is plain in Europe, where a network of state-subsidized airlines still runs a series of cartels to keep the cost of air travel at outrageously inflated levels. Only two national airlines have stood out against these practices - British Airways and the Royal Dutch Airline KLM. Now, under pressure from the European Commission to operate more competitively, European airlines have taken to pointing to the United States, where airlines were deregulated five years ago, saying that experience shows that competition does not work. Smugly, they note that many of the new airlines founded in the wake of deregulation have since been swallowed up by larger competitors; they go on to imply that Europe would not wish to be bothered with that inconvenience. What they overlook, no doubt deliberately, is that the airlines surviving in the United States are more efficient than their progenitors - and that, if they are not, newcomers retain the deregulated right to compete with them.

The next few weeks should bring an interesting test of the cosy European system. British Airways, by far the largest British carrier, announced last week that it plans to buy its largest British competitor, British Caledonian. The explanation is no secret. British Caledonian has been complaining for years that, so long as the British government's regulatory body, the Civil Aviation Authority (CAA), continued to refuse it the right to fly enough routes to be economically viable, it would have no choice but to merge with British Airways.

What this sad tale reveals is the sheer arbitrariness of the regulatory process, even when some of those concerned profess themselves opposed to the cartelization of European air transport. (The British government has been as stalwart as British Airways in its opposition to the European ramp.) A licence to operate aircraft along a commercial route may not be a licence to print money, but it can be a useful defence against bankruptcy. CAA could obviously have helped to keep British Caledonian in the air by giving it access to a larger piece of the cake, the total size of which is determined by bilateral negotiation between European governments, but only at the expense of British Airways, which was sold five months ago to the British public in a hugely successful share flotation. Can it be right that a quasijudicial regulatory agency should have the incidental power to determine the fates of companies into which private people have sunk their funds?

For British Airways (and its competitors), the interest now will be whether the planned merger will be allowed (subject to the approval of the Mergers and Monopolies Commission and/ or the British government) to go ahead. That British Caledonian will retain its name and its existing routes must reflect a calculation that if the merger were a simple takeover, the routes would be up for grabs again. For European air travellers, the chief interest will be whether British Airways, protestations of its zeal for competition have survived the transition from nationalized industry to private company. The British government could and should put the issue to the test by saying that if the merger is allowed, Britain's other small airlines, perhaps half a dozen at the most, will be allowed to compete freely with the surviving giant on any routes to which they can wheedle access. 